

\section{Bollywood in the Hollywood Era: Narratives of \\ Ultra-nationalism, Terrorism and Violence}

\section{Iqbal Shailo}

\section{Introduction}

Some renowned Hollywood and Bollywood movies reflect how government machineries evaluate the political situation and strategic policies of the country in managing geopolitical environments through the construction of security narratives, political rhetoric and geopolitical discourses. These movies reproduce the policies of their statesmen in order to create geopolitical landscapes to combat any threat or danger from inside or outside their political boundaries. The narratives of certain Hollywood movies mostly explain contemporary geopolitics with an emphasis on American defense establishments, US military forces and their tactical and operational capabilities as they disseminate the messages of America's power, strategy and world leadership. While the genre of Bollywood movies reconnects the ideology of division through the establishment of geographies of 'us' and 'them', which set aside the secular image of their struggle against the British rule for about two centuries. The Hindu-Muslim ties in defeating the colonialist are not mirrored by reality in these movies, although the representation of certain communities and nations, mostly Muslim, has been segregated. 
The study is a brief account of certain thematic concepts in Hollywood and Bollywood movies that have been screened with a specific aim to expose the lines of division between us and them. The first section of the study nails down the landscape of American supremacy and ultranationalism while the second section portrays how some Bollywood movies explore identity, violence and terrorism, and more specifically, structures of national identity to create divisions between 'us' and 'them'. The Third section discusses how movies are considered geopolitical narratives and geo-historical texts, which can be employed to understand popular culture as well as to suggest new insights establishing interconnections between colonial politics, popular culture and political awareness used to shape mass opinion and the impacts on the popular consciousness of the mass populations.

\section{American Movies: Geopolitics, Ultra-nationalism, Violence and Identity}

Of late, political and International Relations scholars have shown an immense interest in popular culture, especially film and its impact on the analysis of war, warfare strategies, statecrafts, diplomacy, people's common ideology and global political environment. The influence of American cinema as well as its relation with the US administration and the military establishment explores how movies can be used as social and political tools. 
Much of the themes in Hollywood movies support American ultra-nationalism and masculinity over weakness by providing various ways to solve (geo)political uncertainty and the "very uncertain nature of America itself, through building moral geographies and making clear the lines of division between 'us' and 'them'" (Power and Crampton, 2007:6). Critics believe that American movies function as an ideological state apparatus following the genesis of the Manichean nature of geopolitical discourse (Ibid.).

Dodds believes that American and European cinema has contributed to shape a public opinion and identity as governments along with military and political elites have maintained a close relationship with film companies in order to propagate the ideologies of the day to the masses (Dodds, 2005:77). Citing an example of D.W. Griffith's film The Birth of a Nation (1915), he claims that it constructs a particular narrative of American nationality and Americanized statehood in North America. It is a reflection of American white supremacy that undermines other cultures and races in America. As Ó Tuathail rightly says, "The Birth of a Nation portrays the Ku Klux Klan as the saviours of the white race, as defenders of the virtue of white women, and as representatives of the Christian civilization, a civilization under threat from the innate primitism [sic] and uncontrollable sexual appetite of emancipated African-Americans" (Ó Tuathail,1994:540). Some film makers produce their own concept of heroism, national identity and conflict between good and evil without liaising with US political elites. The Good, the Bad 
and the Ugly (1965) is the best example of a movie that can be "interpreted as highly political in the manner by which they seek to represent 'frontier America', individual heroism and the struggle between good and evil" (Dodds, 2005:77; Short, 1991:178-96).

Like American movies, the former Communist Party of the Soviet Union funded some movies and documentaries under Joseph Stalin in the 1920s and 1930s to be used as propaganda to convey its message to the mass population. Some movies of the 1920s and 1930s are the testimony of the Soviet aggression that reminds us of the geopolitics of the turmoil era between and among the powerful nations. " 'October' (1927) followed by a stream of films in the 1930s such as Two Captains as well as documentaries depicting the Arctic exploits of Soviet pilots" motivated Soviet citizens to explore and to conquer the North Pole (Dodds, 2005:77).

The film demonstrated the communist state under Stalin's regime could handle all responsibility and face any natural or man-made challenges. "These movies helped to construct particular political and cultural identities linked to national prestige and socio-economic development" (Ibid.). The communist party of the USSR approved a number of productions that replicated historical epics such as Ivan the Terrible (1942 and 1946) and anti-American movies such as Court of Honour (1949) in order to inform Russian citizens about the danger and threat of US ideologies (Ibid.). 
Hollywood movies cover various issues, such as national land borders, identity, segregation, spaces of 'otherization', restriction of movement of the population (from Mexico to the USA) and white supremacy. Realizing the 'major shift in the mood of American idealism', Elena dell'Agnese investigated roughly 30 North American movies produced over a period of 65 years on the US-Mexico border issue. Her article titled "The US-Mexico Border in American Movies," highlights the cross border experiences of the South and North as well as the everyday practices, beliefs and geopolitical imagination of common people. It presents several ways of depicting the border: borderland, boundary, demarcation, white supremacy, separation between two borders, identity, fundamental divide between the Haves and Haves not and 'we' and 'they'. She concludes that "together they form a powerful geopolitical representation of Self and Other." Other movies being discussed are: South of the Border (1939, dir. Sherman), The Magnificent Seven (1960, dir. Sturges), The Professionals (1966, dir. Brookes), From Dusk Till Dawn (1996, dir. Rodrigues), Pito Perez se va de bracer (1947, dir. Riera) and Border Incident (1949, dir. Mann).

US movies also challenge national mythologies of the American West (Old West or Wild West) interlinking a more critical engagement with the history of Euro-American imperial expansion and cinematic narration on the construction of Indians and Indian territory, nation, and ethnic identity. Michael J Shapiro’s Hollywood movies, The Pledge (2001, dir. Sean Penn) and 
Paris, Texas (1984, dir. Wim Wenders) scrutinize the US government for disarming and displacing Mexicans and removing their sovereign territories and nationhood (Power and Crampton, 2007). In his study, Shapiro explores "the ways in which movies about the West construct particular geopolitical spaces, reconstruct a sense of 'international relations', represent certain landscapes or reflect upon the fixity or fluidity of borders and boundaries" (Ibid.:7).

Hollywood movies document the past and work as a kind of modern-day geo-politician as Power and Crampton claim in their study. They present an intertextual relationship between movies and WWII and the Second Gulf War in 2003 by explaining that today's Hollywood movies "fulfill the role of geo-politician in producing a pictorial representation of international politics" (Ibid.:7). Their study further explores how movies reveal geopolitical narratives and contemporary geopolitical space. It also provides a special discussion on Saving Private Ryan "in an attempt to understand further how movies figure in the popular political imagination as ways of imaging and enframing global political change" (Ibid.:7).

In the United States, wars were fought twice — on the real battlefield and on film, as Dodds reiterates (2005). The relationship between the government, especially the military establishment, and the film companies is always good and the picturesque "reel" has a tremendous influence on 
the "real" fight because movies catch the vitality of the war while sending celluloid images to the mass population to influence public opinion.

Even Hitler's Germany cooperated closely with film makers for some specific agendas and for over the last 97 years, the US government has cooperated with Hollywood, for example, former president Roosevelt requested the Wilson administration cast 2, 500 mariners in the movie, The Battle Cry of Peace (1915).

After the US was attacked at Pearl Harbor in 1941, the reputation of the Roosevelt administration came under attack. To change the public mood President Roosevelt approved the lease of several planes, ships and other army machines to make a film called Air Force, which was released in 1943. The film reassures Americans by demonstrating that the USA is able to resist any attack by the Japanese on its domestic territory. The Victory Through Air Power (1942) and Why We Fight (1942-43) was a tremendous effort by the US administration to exhibit the strength and power of the US army, to revitalize the morale of the US troops and to inform the public of the US involvement in the conflict with Japan.

Realizing the impact of Hollywood on citizens' imagination, the US military department opened a PR office in Beverly Hills, Los Angeles in post-WWII to monitor and establish relations ranging from providing army equipment to having soldiers participate in the film making process. 
However, the relationship between the US military and Hollywood deteriorated in the 1960s during the decade long Vietnam War. People's resistance and campaigns against the Vietnam War created a moral dilemma between Hollywood and the military establishment. More than 58,000 thousand American servicemen/women died in the war and military records show that many are still missing (MIAs/Missing in Action). The term "'Vietnam Syndrome' was coined in the 1970s in response to fears among American political elites that the humiliation in South East Asia had caused widespread feelings of depression, guilt and loss of moral purpose" (Dodds, 2005:80).

Movies like, The Longest Day (1961), The Green Berets (1968), Apocalypse Now (1979), Hamburger Hill (1985), Platoon (1986), Born on the $4^{\text {th }}$ of July (1995), Top Gun (1986), Courage Under Fire (1996), The Siege (1998) and others underscore the geopolitical representation of world politics and American hegemony over the world system. As Dodds mentions, Hollywood has produced some movies that reflect 'nostalgic representations' of the events that influenced the contemporary American imagination such as Pearl Harbour (2001) [the Second World War], Apollo 13 [US-Soviet space race] (1995), Air Force One [former Soviet terrorists] (1995), Independence Day [alien invasion] (1996), Outbreak [Disease] (1995), and The Rock [weapons of mass destruction] (1996). Thus it can be said that "the popular movie cultures generated by 
Hollywood clearly have a tremendous impact in terms of audience figures, and revenue generation" (Dodds, 2005:83).

Genres and characteristics of American cinema vary from time to time reflecting the reality of social norms and people's aspiration "to be Americanized." The US's desire to rule, police, and oversee world political administrations is no exception.

\section{Indian Movies: Geopolitics, Terrorism, Masculinity and Violence}

Indian movies have captured the themes of terrorism and violence to create an image of danger and fear in the minds of millions of people. Terrorism produces sentiments of fear among the people, and accordingly, popular culture works as an influential media to represent terrorism in Indian films. Critics, mostly Indian diaspora scholars in the USA and the UK, are reviewing and engaging critically to understand how popular culture depicts danger, the identity of 'us' and 'them', politics, security and nation building. Thus film has become a "mimetic of the real world" by providing an important political space for encounters and confrontation for viewers while fostering a renewed interest in popular ideas about global political space to contest, protest, reinforce or reshape foreign policy discourses and 'practices of political elites'. To some extent, there is growing recognition that cinema and geopolitics are interdisciplinary in nature and that the 
reality/representation discourse has been minimized in such a way that film reproduces reality in the guise of ideology.

Masculinity is also tied up in terrorism and violence in Indian movies, specifically the politics of representation of male characters prevails while their female cinematic counterparts are misrepresented in most of the movies. Such a representation embodies the general psyche of the population, as well the heroes are like avatars playing the role of an agent shaping history, culture and tradition. In various movies stereotyped female characters are portrayed in such a way as to associate women with filthiness and weakness.

Violence is also integral to gangster, action-thriller, mafia-centered and Hindu-Muslim conflict movies. However, "neither Indian cinema, nor the real world it is situated in, are free of violence, either in the form of direct aggression, or in more direct, structural forms" (Juluri, 2008: 117). The question arises: does the violence in contemporary Indian movies reflect the societal disharmony or communalism or discrimination between the Haves and Have-nots? Do film makers in India support Gandhi's message of non-violence? If asked, the majority of Indians would likely reply no to such questions. The point I am making, is that most Indian movies on terrorism touch upon the reality of danger and fear and provide the audience with a detailed account of terror related activities. 
The emergence of terrorism in India and its surrounding countries is not a new phenomenon. It took place before the tragedy of $9 / 11$, and remained a recurrent regional problem in South Asia. But none can deny the fact that following the attack on the Twin Towers an immediate interest in terrorism was catalyzed in the cultural, political and academic fields as Jackson rightly notes, "it is now one of the fastest expanding areas of research in the western academic world" (Jackson, 2007:225). According to Cox (1981), many studies on terrorism are state-sponsored and policy oriented in that they discuss how to defeat terrorist activities. It is now time to "explore further the contours of this particular academic field, but also to articulate new intellectual agendas associated with epistemological and political agendas" (Dodds, 2008:229). Although in its infancy, critical terrorism studies (CTS) are timely; they use cultural issues to identify the root causes of terrorism, and visual culture (especially movies and documentaries) can interpret acts of terrorism, strategies, places and locations (Ibid.:229).

Bollywood has released numerous movies on terrorism, and the following are the top ten Indian movies dealing with terrorism in recent years: Sarfarosh, Roja, Bombay, Dil se, Maachis, Fiza, Mission Kashmir, The Hero, A Wednesday, Black Friday (The shocking truth behind the '93 Bombay Blasts). These films, which focus on the terrorist acts in Kashmir in the late 1980s, Rajiv Gandhi’s (the former Prime Minster of India) assassination in 1991, the demolition of Babri Masjid in 1992, serial blasts in Mumbai in 1993, the Kargil War in 1998, the 9/11 attacks in 2001 and the 
Mumbai Attack in 2009, have prompted Indian film makers to create a new genre of film on terrorism and violence. Most of the major cities in India have experienced terror attacks, riots and/or violence. Terrorism has become a focal point of people's discussion and debate, and Indian film makers exploit terrorism to draw people's attention to issues such as identity for commercial purposes.

In the top 10 Bollywood movies featuring terrorism, the characters depicted as terrorists are known by community members. For example, Manisha Koirala, a beautiful local girl in Dil Se, and Tulip Joshi in Dhokka play the role of a suicide bomber. Maachis (1996) narrates the face of terrorism in Punjab in the 1980s when people fought for an independent Khalistan for the Sikh people. Black Friday graphically depicts the 1993 serial bomb-blasts in Mumbai, and similarly Roja, Mission Kashmir and Fana explain the politically charged reality of the Kashmir issue.

Terrorism/or the representation of danger and fear emerged in Hindi movies in Subash Ghai's Karma (1986), which focused on the eruption of terror acts in and around Kashmir. Then came Santosh Sivan's Tamil movie The Terrorist (1999), which depicted a 19-year old women sent to assassinate a leader in South Asia through a suicide bombing. Zameen (2003) is based on the hijacking of Indian Airlines Flight 814 by terrorists and Tango Charlie (2005) depicts three different terrorist events where Indian and paramilitary soldiers fight to reestablish order and 
peace, including Assamese guerilla fighting in the Northeastern part of India, the fight against Naxalites rebels in the state of Bengal and Andra Pradesh, and the state of Kashmir where the Kargil War between India and Pakistan took place.

Roja portrays a common perspective on the Kashmir crisis depicting the way in which Kashmiri militants engage in terror activities and fight against Indian soldiers for the liberty of their soil. Bombay is a love story between a Hindu youth and a Muslim girl caught in a ferocious communal riot and bloodbath. Dil Se is a wonderful story of love and hatred. A girl called Meghna working as a brainwashed terrorist falls in love with a reporter who goes to a Northern territory of India to cover the rebel activities. Meghna is caught between two fires - her human side (love) and her deadly mission (terrorism). Maachis takes a different look at emotions, insecurity, joy and grief while focusing on the duality of being compassionate, caring and loving versus being brutal, cruel and revengeful.

Fiza is a tragic story of a girl in search of her brother who disappeared during the communal riots of 1992-93 in India. Mission Kashmir deals with terrible stories of Kashmir where brutality, killing and revenge take place vis a vis episodes of love and hope emerging in the minds of the protagonists. The Hero: Love story of a Spy is a unique chronicle of an army intelligence officer, Arun Kumar, who is deployed by the Indian Secret Service Agency (called RAW/Research and 
Analysis Wing) across the Kashmir border to gather information about infiltration and terrorist activities in Pakistan. He meets a young lady in the village and recruits one of his spy networks whom he sent to work as a maidservant in the house of a Pakistani Colonel to know about the strategic planning of the country. Later, when her identity is revealed, the girl named Reshma escapes to Canada. Arun goes to Canada and foils the Pakistani terrorists' plan to obtain a nuclear bomb from Canada [it is an error on the part of the director as Canada is not a nuclear power country in the world and does not have any nuclear weapons to sell to any country]. A Wednesday tells the story of a common person who attempts to kill four incarcerated terrorists who threatened the Police Commissioner by setting off six bombs situated in different areas of Mumbai.

Indian movies, especially Bollywood and Tamil, disseminate ideas and representations centered on terrorism through visual media covering millions of Indians from poor labourers and farmers to the middle class, academics, researchers, youth, political workers and elites and, above all government bureaucrats of all ministries including foreign and external affairs. IR scholars have documented how movies "can be used to consider not only how certain 'myths' about the international system are perpetuated on the widescreen, but also in this case to think about how certain individuals and regions are considered to be 'terrorist' in name and substance (Dodds, 2008:230-1). The words of Lacy (2003: 614) are worthy in this regard: 
The Cinema becomes a space where 'common sense' ideas about global politics and history are reproduced and where stories about what is acceptable behaviour from states and individuals are naturalized and legitimated. It is a space where myth about history and the origins of the states are told to a populist audience, one can think of contemporary war movies - such as U571 and We Were Soldiers - that rewrite history into one where historical and normal ambiguity is replaced with certainty.

Movies provide spectators with clues about terrorism, and familiarize people with reality. Sarfarosh is a good example of a contemporary movie on terrorism, danger, fear and identity crisis. It illustrates the distinct characters of the terrorists, their relations with underground terror networks and desire to create instability. They also like to attract media attention to their cause and organization. For example, The Hero: Love story of a Spy reveals the real landscape of the atrocities brought about by terrorists and how they manage to link with other terrorist networks to harm people.

For many years the issue of terrorism has often been discussed in India. Violence, riots, killings, arson, assassinations and slaughter are recurring problems in India. According to the 
Global Terrorism Database (GTD), between 1998 and 2004, India experienced 784 terrorist incidents causing 3,008 deaths: namely, 378 bombings, 298 armed assaults, 52 assassinations, 35 arson and 20 hostage situations. "The Naxalite movement, said to be active in 125 districts in 12 states of India, with an estimated armed cadres of about 18,000, is not a law and order problem to be dealt with by the failed strategy of strong police action by state governments" (Borooah, 2009:93) . Explaining the socio-political condition of the north-east zone of India, Hussain states that "India's northeast is one of South Asia's hottest trouble spots, not simply because the region has as many as 30 armed insurgent organizations operating and fighting the Indian state, but because trans-border linkages that these groups have, and strategic alliances among them, have acted as force multipliers and have made the conflict dynamics all the more intricate" (Hussain, 2004:1). According to the Database, India experienced more than 400 bomb explosions in 2013.

Despite continued hostility, bullying, and threats between rival regional nuclear powers, India and Pakistan, the population of the latter is heavily influenced by Bollywood, as demonstrated by the posters and billboards displaying advertisements and pictures of the heroes and heroines of Indian cinema in the streets across the country. The Pakistanis are basically deprived of rule of law and good governance and perhaps more troublesomely, Pakistan has failed 
to secure its democracy and peace over the years, and of late, the country has become divided between religious and secular sentiments.

The entertainment mechanisms in Pakistan did not flourish in comparison with the Bollywood. Although most Pakistanis do not corroborate with the narratives Bollywood movies employ they are not convinced of India's claims. The theatres of Pakistan become crowded when Indian movies are released and they mostly watch the movies as part of their entertainment. India's movies are the testimonies of their liberal and democratic attitudes. As "India's national identity began to strengthen in the 1960s, jingoistic movies began to emerge" (Kumar, 2012: The New York Times, August 16). Indian movies are widely seen in Pakistan and the demand for local movies is going down. The Pakistan film industry has been urging the government to make a 90 per cent cut in the screening of Indian movies to rescue the sunken domestic film industry (BHNN, 2012), which took a drastic plunge after the 1980s when Bollywood flourished transnationally. For instance, Main Hoon $\mathrm{Na}$ highlights the mending of relations between the two neighbours; stereotypes in Ghaddar et al, shows Pakistanis depicted in very traditional garbs and projecting negativity; and even Yash Chopra's Veer Zara was poorly made. Pakistani director Sabiha Sumar's Khamosh Pani depicts many issues that relate to partition and find resonance in contemporary scenarios. 
Rahimulla Yusufzai's words can be mentioned here: "the popularity of Indian movies like Roja, Border, Mission Kashmir and Refugee in the Pakistani home video market. These movies which depict the Indian view of Kashmir Issue, are being secretly rented after a ban by the government...Video stores in Islamabad [of Pakistan] report brisk demand for Bollywood movies, including the 'anti-Pakistani' ones" (Athique, 2008:497-98).

Other movies, such as Slumdog Millionaire (2008) are worthy of mention here. This is a film centered on a penniless Mumbai slum boy's horrific story as told by British Director Danny Boyle, who cast all the characters from India and non-resident Indians. The film received 10 Academy Awards, while garnering fame in the USA, Canada, and the UK. As such, a good and constructive movie on national and regional security and cooperation issues can have a greater impact on its immediate neighbours like Bangladesh, Pakistan, Nepal, Sri Lanka and Bhutan.

Accordingly, like Hollywood movies, Indian movies also develop and maintain linkages with other global media corporations as " Bollywood movies and film music are gradually moving out of the "South Asian" diasporic market into American or British public culture more broadly" (Punathambekar and Kavoori, 2008:8). NRI (non-resident Indians) also play a great role in India's quest to see monetary returns flowing into the mainstream economic growth of India. Bollywood employs more than 2.5 million people and sells over 4 billion in tickets (Thussu, 2008). 
India is within the world's top six film producing nations and over the past three decades it has produced more movies annually than many other countries in the world.

\section{Hollywood and Bollywood: Geopolitical Text and Public Opinion}

Given the above discussion, it is apparent that movies are considered geopolitical narratives and geo-historical texts, and can be employed to understand popular culture as well as to define geopolitical discourses. The aforementioned American films highlight contemporary geopolitics with much emphasis on American defense establishments, US military forces and their tactical and operational capabilities, while disseminating the message of America's power, strategy and world leadership. The narratives used often reflect geopolitical landscapes of their empire used to combat any threat or danger from inside or outside their boundary. These movies explore how statesmen and generals evaluate the political situation and strategic policies of the country and how the USA handles changing geopolitical environments while constructing security narratives, political rhetoric and geopolitical discourses.

Bollywood's engagement at home and abroad and especially in the regions is remarkable.

It not only touches the upper middle class, middle class, lower middle class families and mass population but delivers messages simultaneously to political elites and bureaucrats who design 
strategy for foreign policy and regional relations. Different genres of regional and domestic politics are reflected in Indian movies. For instance, colonial abuse, post-colonial deprivation, identity crisis between communities and communal disharmony are the subjects of Indian films, and audiences take narratives and discourses on danger and fear to heart. Such coercive narratives against ethnicity in Indian movies have reasonably undermined India's cautiously constructed concept of identity, pluralism and secularism that were founded in the postcolonial state under the leadership of Nehru, the former prime minister of India.

\section{Concluding Remarks: Hollywood and Bollywood}

The discussed Hollywood and Bollywood movies create meaning through narratives as well as raw images, dialogues, settings, and stories that interpret historical contexts and provide an understanding of political, social and cultural connotations. It sheds light on the colonial era to present multi-focal perspectives of present-day American and Indian societal values. Such an analysis goes beyond the text to suggest new insights into the establishment of interconnections between colonial politics, popular culture and political awareness to shape the opinions of mass

populations. Dodds contends that there exist a number of examples where governments and 
political elites have used cinema to manipulate public opinion in order to create an image, especially during periods of war and crisis (Dodds, 2005).

However, films are not just an entertainment device but rather a vocal media for contestation around geopolitical meaning, scripting and connotation with the ability to influence mass opinions impacting popular consciousness. These movies could work as a matrix of soft power either to contest political agendas enhancing cultural integrity through a variety of set agendas ranging from collective nationhood, regional integration to shared values.

\section{BIBLIOGRAPHY:}

Athique, Adrian.2008. "A Line in the Sand: The India-Pakistan Border in the Films of J.P.

Dutta," South Asia: Journal of South Asian Studies, Vol. 31(3): p. 472-499 
BHNN (Bollywood Hungama News Network).2012 [December 17]. "Pakistani film producers rally to ban Indian films"

Borooah, Vanik.2009. “Terrorist Incidents in India, 1998-2004: A Quantitative Analysis of Fatality Rates,” Terrorism and Political Violence, Vol. 21: p. 476-498

Cox, R.1981, “Social forces, states and world orders," Millennium, Vol. 10: p. 123-126

Crampton, Andrew and Power, Marcus.2005. "Frames of reference on the geopolitical stage: Saving Private Ryan and the Second /Second Gulf War Intertext," Geopolitics, Vol. 10(2): p. 244-265.

Dodds, Klaus.2005. Global Geopolitics, A Critical Introduction. Harlow: Pearson Education; p.77-78. 
Global Terrorism Database (GTD): for details: https://www.start.umd.edu/gtd/

Hussain, Akmal.2005. “Bangladesh’s New Foreign Policy Direction in Southeast and East

Asia: Perspective and Goals," Journal of International Development and Cooperation, Vol. 12(1):

p. 1-14.

Jackson, R.2007. “Introduction: The case for critical studies," European Political Science,

Vol. 6(3): p. 225-227.

Juluri, Vamsee.2008, "Our Violence, Their Violence: Exploring the Emotional and

Relational Matrix of Terrorist Cinema," In Anandam P. Kavoori and Aswin Punathambekar (eds.)

Global Bollywood, New York University Press: p. 117-130.

Kavoori, Anandam and Punathambekar, Aswin.2008. "Introduction: Global Bollywood," In Anandam Kavoori and Aswin Punathambekar (eds.) Global Bollywood, New York University Press. 
Kumar, Raksha. 2012. "How Bollywood's Views on Pakistan Evolved," The New York Times (August 16).

Lacy, M.2003. “War, Cinema and moral anxiety,” Alternatives, Vol. 28: p.611-636.

Ó Tuathail, Gearóid.1994. "Displacing geopolitics: writing on the maps of global politics," Environment and Planning D: Society and Space, Vol. 12: p. 525-46.

Power M and Crampton, Andrew.2007. "Reel geopolitics: Cinemato-graphing political space," In Marcus Power and Andrew Crampton (eds.) Cinema and Popular Geo-Politics, Routledge: p. 6-7.

Punathambekar, Aswin and Kavoori, Anandam.2008: "Introduction," In Aswin Punathambekar and Anandam Kavoori (eds.) Global Bollywood, New York University Press.

Short, J.1991. Imagined Country, London: Routledge.

Thussu, Daya Kishan.2008. “The Globalization of "Bollywood”: The Hype and Hope,” In Anandam P. Kavoori and Aswin Punathambekar (eds.) Global Bollywood, New York University Press: p. 97-116. 